Vol. 11, No. 1, 2021

\title{
THE PRINCIPLE OF CREATING \\ A "SMART" ELECTRICITY METER IN ELECTRIC TRACTION NETWORKS WITH STOCHASTIC ELECTROMAGNETIC PROCESSES
}

\author{
Mykola Kostin $^{1}$, Tetiana Mishchenko ${ }^{1}$, Oksana Hoholyuk ${ }^{2}$ \\ ${ }^{1}$ Dnipro National University of Railway Transport named after Academician V. Lazaryan, Dnipro, Ukraine \\ ${ }^{2}$ Lviv Polytechnic National University, Lviv, Ukraine \\ Ukrainenkostin@ukr.net,Ukrainemishchenko_tn@ukr.net,oksana.p.hoholyuk@lpnu.ua
}

\begin{abstract}
Voltage and current are sharply variable random (stochastic) processes in traction networks of DC electric transport systems. As a result, electronic and hybrid electricity meters used in electric systems measure electric power with a large relative error that significantly exceeds that of their accuracy class. In this paper the principle of developing smart meters for accounting the electricity transmitted from traction substations to electric rolling stock through a traction network is proposed. Proposed ideas are developed on the basis of the random processes correlation theory. The meter operates in real time and monitors not a set of realizations of random voltage and current processes, but their deterministic characteristics, that is, time functions of mathematical expectations and variances which make up the background of its operating principle. The experimental implementation of the proposed principle has been conducted in the feeder zone of an A-B section of the GisDnieper Railway of Ukraine, where registration and processing of realizations of stochastic voltage and current processes obtained in real operation mode has been done. The ratios obtained for active and reactive power can be applied not only for traction power grids, but also for electric networks of external power supply of DC electric traction systems as the basis for the "smart meter" design.
\end{abstract}

Key words: smart meter, voltage, current, power, random process, principle, electricity, stochastic, mathematical expectation, variance function, correlation function.

\section{Introduction}

One of the fields of Smart Grid technological solutions is the development and creation of measuring instruments and devices, and in particular, "smart meters" in order to determine the amount of electricity and its losses in electrical networks [1]. The solution to this problem for traction networks and external power supply networks of electric transport systems is urgently needed.

At present, electronic, induction and hybrid electricity meters are used at traction substations (TP) supplying traction networks of electrified railways in Ukraine $[2,3]$. In particular, modern electronic meters of the "Alpha" type with an accuracy class of 0.5 are used at the input of DC transformer substations, at the connections for commercial metering of energy and powerful non-traction consumers. However, these meters can operate with high accuracy, practically without errors, only in steady-state modes with sinusoidal voltages and currents and in symmetrical systems. In other cases, that is, in other systems being DC electric traction systems (ETS) (which will be shown below), existing meters measure energy characteristics with significant errors [4-6]. Besides, determination of reactive energy is carried out only at the fundamental harmonic of $50 \mathrm{~Hz}$, and possible energy fluxes of other harmonics are not taken into account. Also, at a current distortion factor $I_{D}$ exceeding $25 \%$, the electronic meter operates beyond its accuracy class [2].

Considering the induction meters located in the traction circuits with rectified voltages and currents, the situation with the electricity measurement seems to be undefined and incorrect even more. It is caused by using out-of-date induction meters with a low accuracy class of 2.0 there and, therefore, with a high measuring error. According to studies shown in [3], the mathematical expectation of the error $m_{\gamma}$ is at least $5 \%$ and its average deviation $\sigma_{\gamma}=2.57 \% \ldots$ At the same time, the authors of [3] argue that the actual value of the maximum error of induction meters in the feeder circuits of DC transformer substations should be determined as $\gamma_{\max }=m_{y}+2 \cdot \sigma_{y}$ and then it will be 
equal to $10.4 \%$. As a result, measuring results of such meters are rather poor.

In traction networks, the above presented tasks become much more complicated and measurement errors significantly increase, since voltages and currents are non-ergodic random (stochastic) processes over there (Fig. 1), considerably complicating the development of "smart electricity meters".

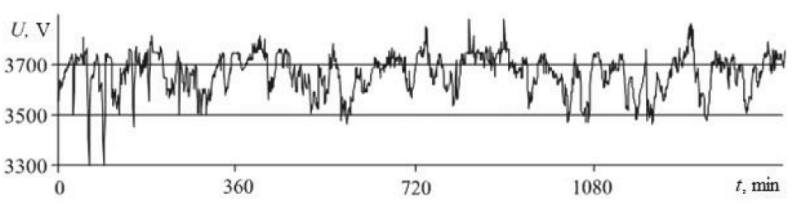

a)

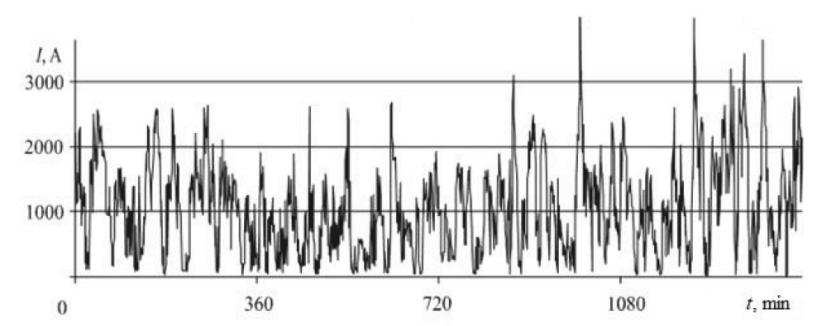

b)

Fig. 1. Registered stochastic processes of voltage (a) and current (b) changes in a DC traction network.

Therefore, in this paper, the approach to the development of "smart meters" suitable for measuring the consumption and losses of active and reactive power in power grids with the specified character of voltage and current changes is proposed.

\section{Mathematical formulation of the problem}

Since the voltage $U(t)$ and current $I(t)$ in the traction power grid, despite being rectified, are sharply variable in time random (stochastic) processes, the active $W_{a}$ and reactive $W_{r}$ energy transmitted through the traction network during the time $[0 \ldots T]$ are determined by expressions for the corresponding powers $P, Q_{f}$ and voltage and current components:

$$
\begin{aligned}
& W_{a}=\int_{0}^{T} P(t) d t=\int_{0}^{T} U_{a}(t) \cdot I_{a}(t) d t, \\
& W_{r}=\int_{0}^{T} Q_{f}(t) d t=\int_{0}^{T} U_{r}(t) \cdot I_{r}(t) d t,
\end{aligned}
$$

where $U_{a}, U_{r}, I_{a}, I_{r}$ are active and reactive components of voltage and current in each of many implementations of stochastic $U(t)$ and $I(t) ; Q_{f}$ is a reactive power whose essence and definition are still being discussed nowadays with different concepts being proposed [7-15].
According to the history of appearing the concepts of reactive power, one of the first ones to be considered is the Budeanu concept [7]. It is based on the frequency representation of voltages and currents, according to which the reactive power is defined as a sum of reactive powers of various harmonics obtained by the classical Fourier expansion of voltages and currents:

$$
Q_{B}=\sum_{k=1}^{n} U_{K} \cdot I_{K} \cdot \sin \left(\psi_{u_{K}}-\psi_{i_{K}}\right) \ldots
$$

but such an approach to determining the reactive power, firstly, does not describe the actual electric power processes and, secondly, does not ensure the balance of the components of the total power $S$ in the following form:

$$
S^{2} \neq P^{2}+Q_{B}^{2}
$$

Most researchers $[9,11]$ consider the concept of Fryze [8] to be more promising, which, firstly, is aimed to preserve the functional nature of the energy properties revealing in electrical circuits during sinusoidal and non-sinusoidal processes and, secondly, ensures the fulfillment of the power balance:

$$
S^{2}=P^{2}+Q_{f}^{2} .
$$

If it is necessary to estimate the technological losses in the traction network, they are determined through the same values-arguments $P, Q_{f}, I_{a}, I_{r}$ [16]:

a) main losses

$$
\Delta W_{0}(t)=R \cdot I_{a}^{2}(t) T=R \frac{P^{2}(t)}{U_{e}^{2}(t)} T,
$$

b) additional losses

$$
\Delta W_{a d}(t)=R \cdot I_{r}^{2}(t) T=R \frac{Q_{f}^{2}(t)}{U_{e}^{2}(t)} T,
$$

where $R$ is an active resistance of the investigated section of the traction network; $U_{e}$ is the value of effective voltage.

Basing on expressions (1), (2) and (6), (7), it is possible to draw a conclusion that for measuring active and reactive power, as well as technological losses, a "smart meter" operating in real time must monitor the time dependences of power $P(t), Q_{f}(t)$ or active and reactive components of voltage and current in a certain time interval $\Delta t$ in each of the many implementations of random processes $U(t), I(t) \ldots$ 
In authors' opinion, the first option is more obvious and simpler; therefore, in this work, it is proposed for solving the problem.

\section{Theoretical background for creating a smart meter}

Let us imagine registered implementations $U_{1}, U_{2}$, $\ldots U_{i}, \ldots U_{n}$ of random voltage process in the traction network and registered implementations $I_{1}, I_{2}, \ldots I_{i}, \ldots$ $I_{n}$ of random current process in the same network synchronously recorded over a certain time interval $[0 \ldots T]$ (Fig. 2).
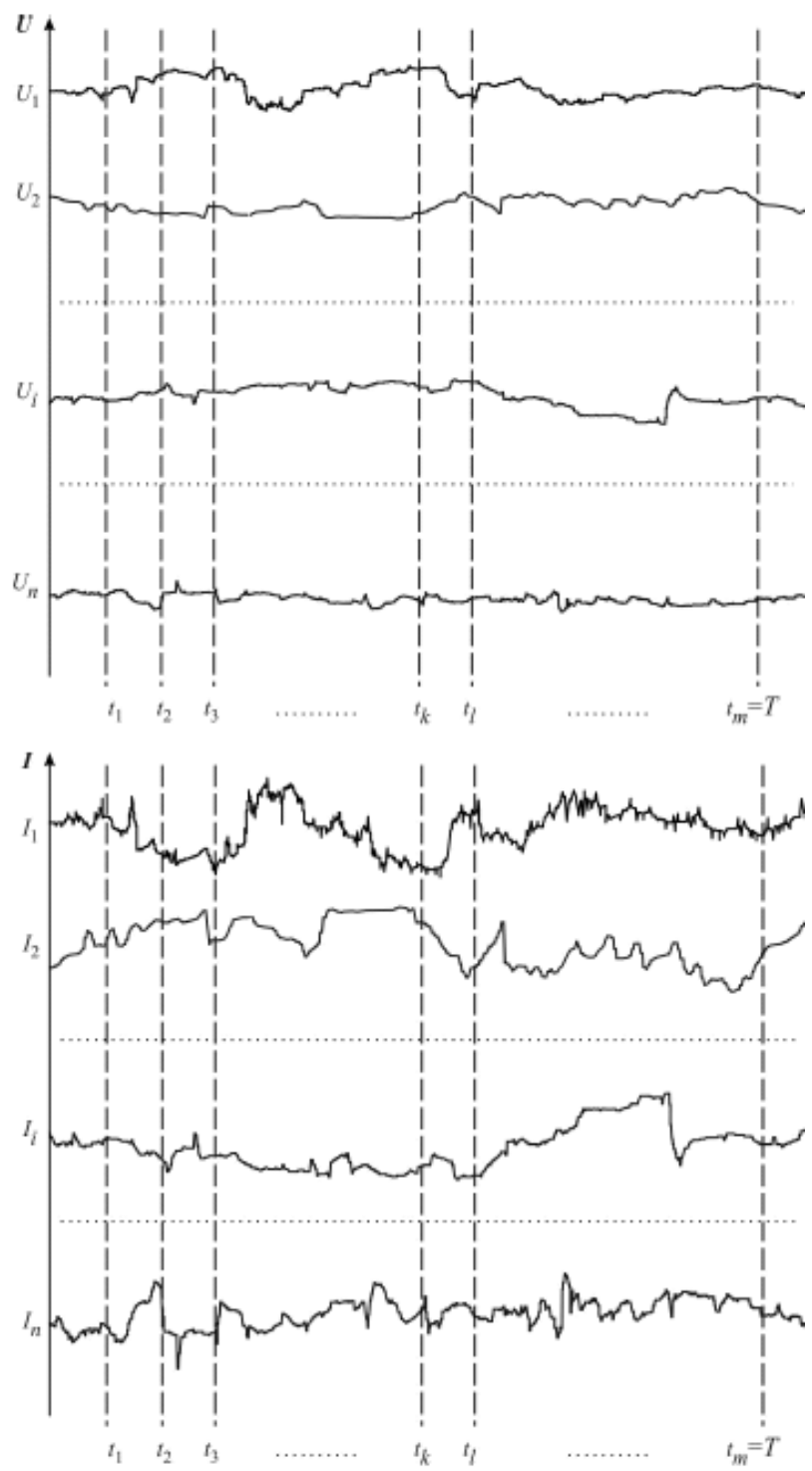

Fig. 2. Realization of random processes of voltage and current [17].

Let us quantize these realizations with necessary step $\Delta t$ equal to $t_{l}-t_{k} \ldots$ (according to the Kotelnikov theory [18]). Let us write the expression of the stress correlation functions $K_{U}\left(t_{k}, t_{l}\right)$ and current $K_{I}\left(t_{k}, t_{l}\right)$ according to $[19,20]$ :

$$
\begin{gathered}
K_{U}\left(t_{k}, t_{l}\right)=\frac{\sum_{i=1}^{n} U_{i}\left(t_{k}\right) \cdot U_{i}\left(t_{l}\right)}{n-1}-m_{U}\left(t_{k}\right) \cdot m_{U}\left(t_{l}\right)= \\
=\frac{\sum_{i=1}^{n} U_{i}\left(t_{k}\right) \cdot U_{i}\left(t_{k}+\tau\right)}{n-1}-m_{U}\left(t_{k}\right) \cdot m_{U}\left(t_{k}+\tau\right), \\
K_{I}\left(t_{k}, t_{l}\right)=\frac{\sum_{i=1}^{n} I_{i}\left(t_{k}\right) \cdot I_{i}\left(t_{k}+\tau\right)}{n-1}- \\
-m_{I}\left(t_{k}\right) \cdot m_{I}\left(t_{k}+\tau\right),
\end{gathered}
$$

where $m_{U}, m_{I}$ are mathematical expectations of voltage and current at the corresponding moments of time $t_{k}, t_{l} \ldots$

After some transformations, the effective values of voltage and current for $t_{k}=t_{l}$, that is, for $\tau=0$ have been obtained [17]:

$$
\begin{gathered}
U_{e}(t)=\sqrt{D_{U}(t)+m_{U}^{2}(t)}, \\
I_{e}(t)=\sqrt{D_{I}(t)+m_{I}^{2}(t)},
\end{gathered}
$$

where $D_{U}(t), D_{I}(t)$ are time functions of voltage and current dispersion.

Then the functional dependence of the total power on the time interval $[0 \ldots T]$ can be defined as:

$$
\begin{aligned}
& S(t)=U(t) I(t)= \\
& =\sqrt{[D(t)+m(t)] \cdot[D(t)+m(t)]} .
\end{aligned}
$$

The estimation of the cross-correlation function of random processes $U(t)$ and $I(t)$ can be written as [19]:

$$
\begin{gathered}
K_{U I}\left(t_{k}, t_{l}\right)=\frac{\sum_{i=1}^{n}\left[U_{i}\left(t_{k}\right)-m_{U}\left(t_{k}\right)\right] \cdot\left[I_{i}\left(t_{l}\right)-m_{I}\left(t_{l}\right)\right]}{n}= \\
=\frac{\sum_{i=1}^{n} U_{i}\left(t_{k}\right) \cdot I_{i}\left(t_{l}\right)-U_{i}\left(t_{k}\right) \cdot m_{I}\left(t_{l}\right)-}{n} \ldots \\
\ldots \frac{-I_{i}\left(t_{l}\right) \cdot m_{U}\left(t_{k}\right)+m_{U}\left(t_{k}\right) \cdot m_{I}\left(t_{l}\right)}{n} .
\end{gathered}
$$

The summands in (13) at $\tau=0$ can be represented as follows:

- first summand:

$$
\frac{\sum_{i=1}^{n} U_{i}\left(t_{k}\right) \cdot I_{i}\left(t_{l}\right)}{n}=\frac{\sum_{i=1}^{n} U_{i}\left(t_{k}\right) \cdot I_{i}\left(t_{k}\right)}{n}=P\left(t_{k}\right)
$$


- second summand:

$$
\frac{\sum_{i=1}^{n} U_{i}\left(t_{k}\right) \cdot m_{I}\left(t_{l}+\tau\right)}{n}=m_{I}\left(t_{k}\right) \cdot m_{U}\left(t_{k}\right)
$$

- third summand:

$$
\frac{\sum_{i+1}^{n} I_{i}\left(t_{l}\right) \cdot m_{U}\left(t_{k}\right)}{n}=m_{I}\left(t_{k}\right) \cdot m_{U}\left(t_{k}\right) ;
$$

- fourth summand:

$$
\begin{aligned}
& m_{U}\left(t_{k}\right) \cdot m_{I}\left(t_{l}\right)=m_{U}\left(t_{k}\right) \cdot m_{I}\left(t_{k}+\tau\right)= \\
& =m_{U}\left(t_{k}\right) \cdot m_{I}\left(t_{k}\right)
\end{aligned} .
$$

Taking into account expressions (14)-(17), formula (13) for the mutual correlation function $K_{U I}$ will take the form:

$$
K_{U I}\left(t_{k}, \tau=0\right)=P\left(t_{k}\right)-m_{U}\left(t_{k}\right) \cdot m_{I}\left(t_{k}\right) \ldots
$$

Hence the active power at the moment of time $t=t_{k}$ is defined as:

$$
P\left(t_{k}\right)=K_{U I}\left(t_{k}, \tau=0\right)+m_{U}\left(t_{k}\right) \cdot m_{I}\left(t_{k}\right),
$$

and after obtaining the values $P\left(t_{1}\right), P\left(t_{2}\right), \ldots, P\left(t_{k}\right)$, $\ldots, P\left(t_{m}\right)$, values $K_{U I}\left(t_{1}\right), K_{U I}\left(t_{2}\right), m\left(t_{1}\right), m\left(t_{2}\right)$, $\ldots, m\left(t_{k}\right), \ldots, m\left(t_{m}\right)$ and their approximation, a functional dependence at the time period $[0 \ldots T]$ is obtained:

$$
P(t)=D_{U I}\left(t_{k}\right)+m_{U}(t) \cdot m_{I}(t) .
$$

Taking into account the expressions for the total and active powers, the reactive power according to the Fryze concept [8] can be written in the form of an hourly functional dependence:

$$
\begin{aligned}
& Q_{\phi}=\sqrt{S^{2}(t)=P^{2}(t)}= \\
& =\sqrt{\left[D_{U}(t)+m_{U}^{2}(t)\right] \cdot\left[D_{I}(t)+m_{I}^{2}(t)\right]-} \\
& \frac{-\left[D_{U I}\left(t_{k}\right)+m_{U}(t) \cdot m_{I}(t)\right]^{2}}{}
\end{aligned}
$$

where $D_{U I}$ is the time function of voltage and current mutual dispersion.

Substituting expressions (20) and (21) into formulae (1), (2) and (6), (7), we obtain calculated relations - the basis of operating the "smart" electric meter, that is, its fundamental capabilities to determine the active and reactive power, as well as technological energy losses:

$$
\begin{gathered}
W_{a}=\int_{0}^{T} P(t) d t=\int_{0}^{T}\left[D_{U I}(t)+m_{U}(t)\right] d t, \\
W_{r}=\int_{0}^{T} Q_{f}(t) d t= \\
=\int_{0}^{T} \sqrt{\left[D_{U}(t)+m_{U}^{2}(t)\right] \cdot\left[D_{I}(t)+m_{I}^{2}(t)\right]-} \\
\quad-\left[\frac{\left[D_{U I}(t)+m_{U}(t) \cdot m_{I}(t)\right]^{2}}{d} \cdot d t,\right. \\
\Delta W_{0}(t)=R \cdot \frac{\left[D_{U I}(t)+m_{U}(t) \cdot m_{I}(t)\right]^{2}}{U_{e}^{2}(t)} \cdot T, \\
\Delta W_{a d}(t)= \\
=R \cdot \frac{\left[D_{U}(t)+m_{U}^{2}(t)\right] \cdot\left[D_{I}(t)+m_{I}^{2}(t)\right]-}{U_{e}^{2}(t)} \\
-\frac{\left[D_{U I}(t)+m_{U}(t) \cdot m_{I}(t)\right]^{2}}{U_{e}^{2}(t)} \cdot T .
\end{gathered}
$$

As follows from expressions (22)-(25), the determination and, consequently, the measurement of power and power losses with the smart meter is based on the assessment of such probabilistic characteristics of random processes $U(t), I(t)$ as their time functions of mathematical expectations and variances. Their form can be illustrated by the example.

\section{Experimental support of creating a smart} meter

Obtaining the required probabilistic characteristics $m_{U}(t), m_{I}(t), D_{U}(t), D_{I}(t), D_{U I}(t)$ was carried out by probabilistic-statistical processing [20] of synchronously recorded time dependencies (registered realization oscillograms) of random voltage $U(t)$ and current $I(t)$ processes in the traction network under the real operating conditions of the $\mathrm{AB}$ section (feeder zone) of the Dnieper railway of Ukraine. For practical analysis, 30 realizations of voltage and current were obtained. Some of them are presented below.

As it is shown in Fig. 3, the voltage in the traction network is characterized by significant continuous fluctuations in the range of 2960-3930 V, thereby exceeding the nominal values of $3300 \mathrm{~V}$. A histogram form (Fig. 4), small value of the asymmetry coefficient $\left(A_{s}=-0.13 \ldots-0.33\right)$ and kurtosis $\left(E_{x}=0.19 \ldots 0.34\right)$ indicate the normal law of stress distribution in the sections of the process realizations. According to Fig. 5 , deterministic expectation functions $m_{U}(t)=\bar{U}(t)$ 
and variance $D(t)$ obtained by sampling a group of 30 realizations $U(t)$ like in Fig. 3 indicate the non-stationarity of the random stress process.

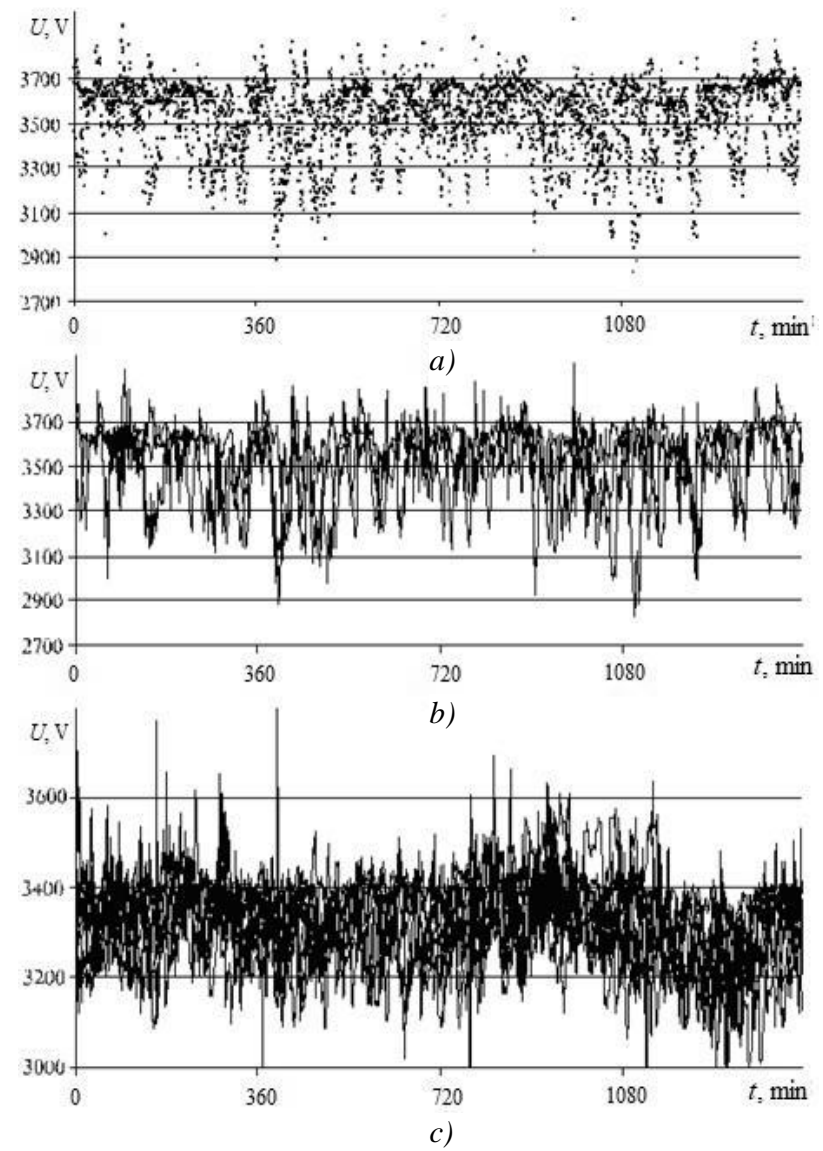

Fig. 3. Voltage at the A-B section of the traction network of the GisDnieper railway (Ukraine): $a$-field of possible values; $b$ - three temporary registered realization oscillograms; $c$-ten temporary registered realization oscillograms.

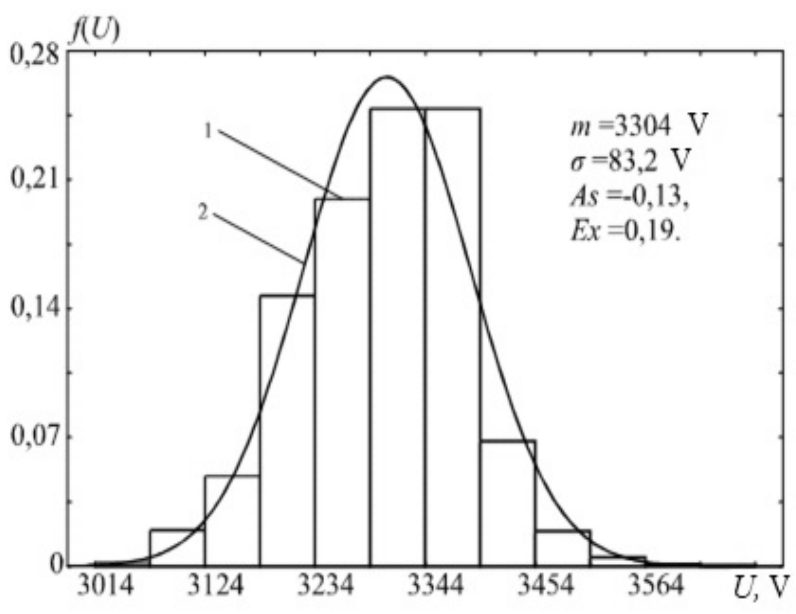

Fig. 4. Statistical (1) and theoretical (2) voltage distribution in the A-B section.

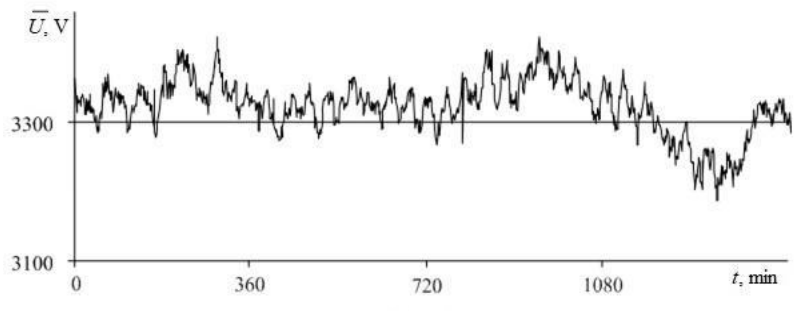

a)

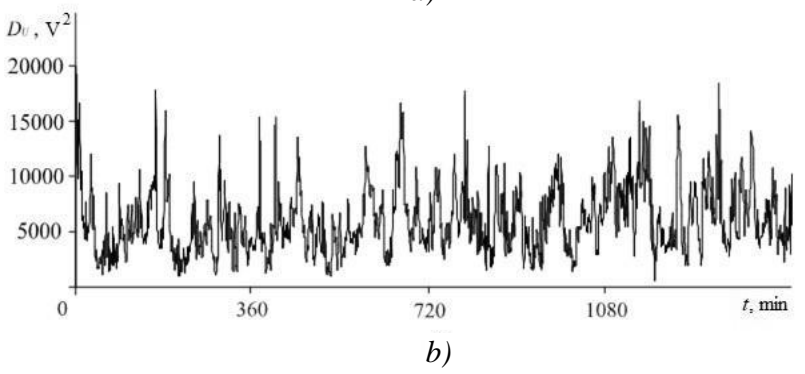

Fig. 5. Time functions of the mathematical expectation (a) and dispersion $(b)$ of the voltage

in the traction power network in the A-B section.

The traction current in the investigated A-B section is characterized by sharp wave-like changes in the range from -150 to 2900 A (Fig. 6). The type of statistical distribution (Fig. 7, curve 1), as well as the values of the coefficient $A_{s}=1,26 \ldots 2,03$ and excess $E_{x}=1,45 \ldots 4,8$ indicate a non-Gaussian current distribution law, it clearly deviates towards lower current values. Probability characteristics $\bar{I}(t)=m_{I}(t)$ and $D_{I}(t)$ (Fig. 8) indicate a significant non-stationarity of the current changing process.
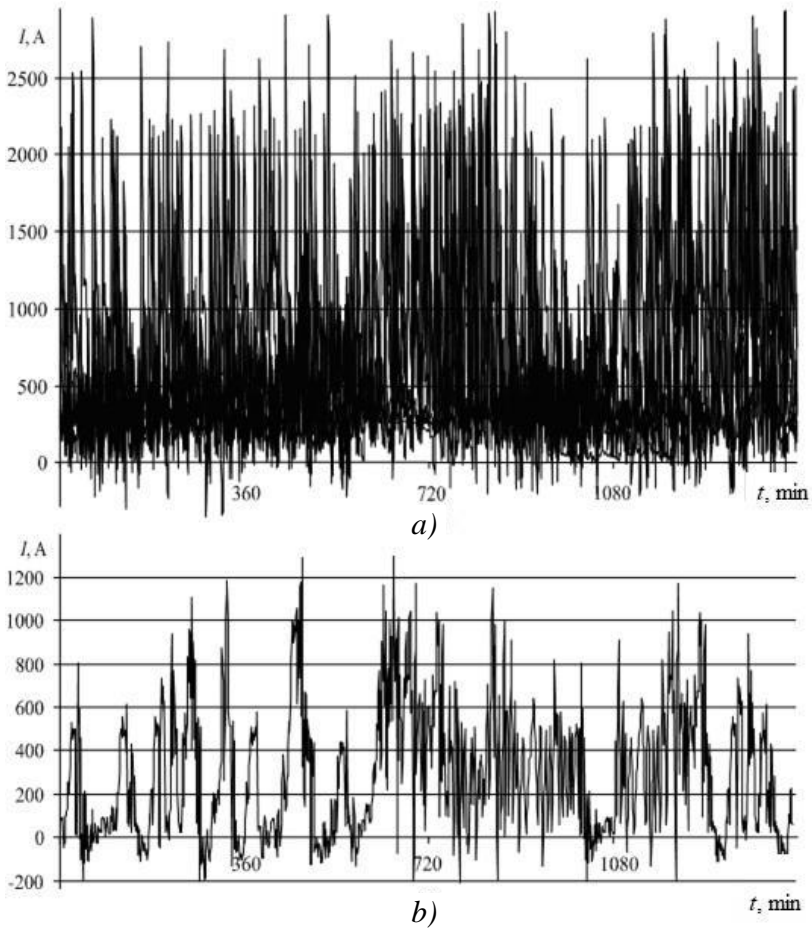

Fig. 6. Time dependences of traction currents in section A-B: $a-8$ realizations (registered oscillograms), $b$ - one implementation. 


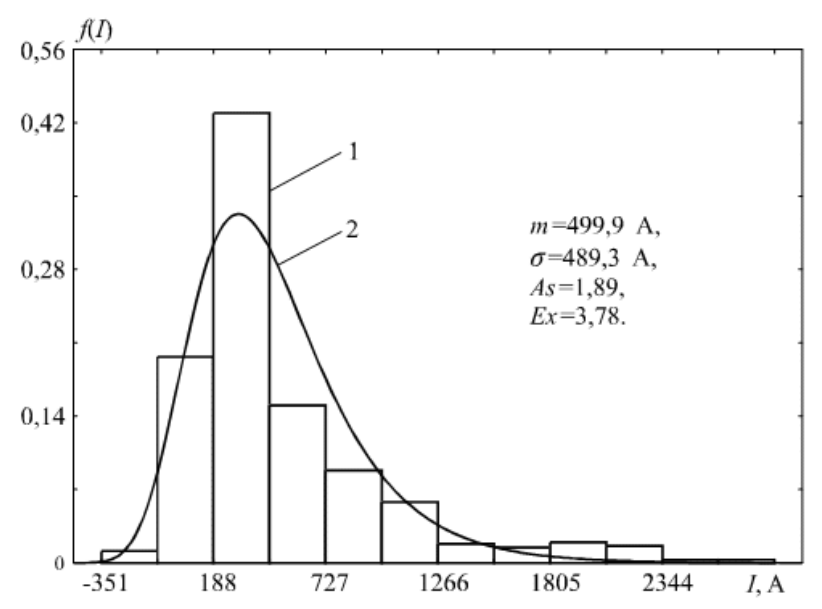

Fig. 7. Statistical (1) and theoretical (2) distribution of traction current in the $A-B$ section.
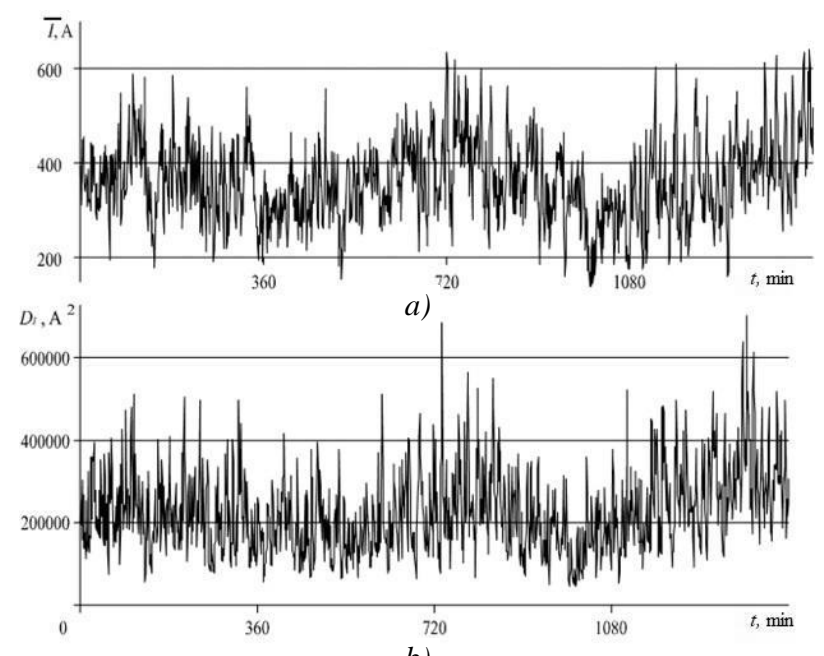

b)

Fig. 8. Time functions of the mathematical expectation (a) and dispersion (b) of the traction current in the A-B section.

Time deterministic functions of mathematical expectations obtained above $m_{U}(t), m_{I}(t)$ and variances $D_{U}(t), D_{I}(t), D_{U I}(t)$ (Fig. 5, 8, 9), according to expressions (22)-(25), underlie the operation of a "smart meter" in real time by monitoring the graphs of these functions.

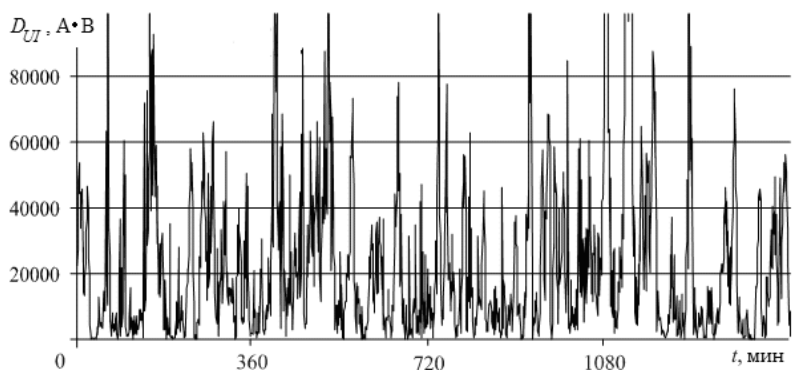

Fig. 9. Time function of mutual dispersion of voltage and current on the A-B section of the traction network of the Dnieper railway (Ukraine).

\section{Conclusions}

1. Due to the stochastic nature of voltage and current changes in the traction networks of electric transport systems, the existing types of electricity meters, including modern electronic ones, give significantly erroneous results for measuring electricity, which necessitates the development of smart meters for these purposes.

2. Taking into account the causal relationship between erroneous measurements of existing meters and the random nature of changes in electric traction voltages and currents, the principles of creating smart meters should be based on taking into account the probabilistic characteristics of these voltages and currents.

3. The proposed principle of creating a smart meter assumes its operation in real time when it monitors temporal deterministic (non-random) functions of mathematical expectations and variances of stochastic voltage and current processes in traction networks.

4. The calculated ratios obtained for active and reactive energies, as the basis for the principle of creating a "smart" meter for traction networks, are also applicable to external power supply networks of DC electric transport systems.

\section{References}

[1] Smart meters: saving energy into the future https://energysavingtrust.org.uk/smart-meterssaving-energy-future/

[2] D. O. Bosiy and O. M. Sinyogina, "Accounting of the electric power by modern electronic meters under condition of harmonic disturbances", Electricity transport, no. 7, pp. 98-105, 2014. (in Ukrainian)

[3] V. S. Skryabinsky, D. V. Sotnikov, and Yu. B. Manusov, Features of energy accounting at traction railway substations, Kiev: IED, 1978. 28 p. - (Preprint - 170 ISDAN Ukrainian SSR). (in Russian)

[4] V. V. Kiselev and I. S. Ponomarenko. "Influence of non-sinusoidal voltage and current on the readings of electronic electricity meters", Prom. Energy, no. 2, pp. 40-45. 2004. (in Russian)

[5] A. L. Gurtovtsev, "On the total limiting and real errors of electronic electric meters", Electricity. no. 7, pp. 16-23, 2007. (in Russian)

[6] S. P. Denisyuk and V.O. Kravtsov, "Evaluation of measuring accuracy of power components in systems with electric power conveters", "PSE-2008", Part 1, pp. 61-66, 2008. (in Ukrainian)

[7] C. Budeanu, "Problem de la presence der puissance's reactive dans les installation de production et 
distribution d'energie", Rap. Et. Discuss Sar la puissance reactive, 1929, Pt. 3. pp. 117-218.

[8] S. Fryze, Wirk, Blind- und- Scheinleisteng in Elektrisch Stromkreisen mit nicht-sinsformigen Verlauf von Strom und Spannung / ETZ. - Bd.53, 1932.

[9] V. E. Tonkal, A. V. Novoseltsev, S. P. Denisyuk and others, Energy balance in electrical circuits, K.: Nauk. Dumka, p. 312, 1992.(in Russian)

[10] K. S. Demirchyan, "Reactive power for the case of non-sinusoidal functions", Izv. RAS. Energy, no. 1, pp. 3-18, 1992. (in Russian)

[11] Yu. L. Saunko, Reactive pushing in power supply systems with non-linear loading: Dissertation thesis for D.Sc degree on specialty 09.05.05 "Theoretical electrical engineering", Lviv, 36 p., 2003. (in Ukrainian)

[12] L. Czarnecki, "On some misinterpretations of the instantaneous reactive power pq theory", IEEE Trans. on Power Electronics, vol.19, no. 3, pp. 828-836, 2004.

[13] I. F. Domnin, G. G. Zhemerov, D. S. Krylov et al., Modern theories of power and their use in converter systems of electronics, Tekhnichna elektrodynamika. That. vip., part 1, pp. 80-91, 2004. (in Russian)

[14] H. Akagi et al., "Instantaneous power theory applications to conditioning", Willey-IEEE Press, 2007, 379p, ISBN 978-0-470-10761-4.

[15] R. Herrera et al., Present point of view about the instantaneous power theory IEEE Trans. on Power Electronics, vol. 2, Iss. 5, pp. 484-495, 2009.

[16] A. Szelag, M. Kostin, and A. Nikitenko, "Losses of Recovered Electric Energy in the Elements of a DC Electric Transport System", Power Electronics, IEEE, pp. 412-418, 2016.

[17] A. V. Nikitenko and M. O. Kostin, Korelyatsiydispersed method of determining the storage capacity in the annexes of electric transport, Science and Progress of Transport. Dnipropetrovsk National University of Retail Transport. No. 2, (in Ukrainian) pp. 64-73. 2013. http://nbuv.gov.ua/UJRN/vdnuzt_ 2013_2_9

[18] I. S. Gonorovskiy, Radio circuits and signals, - M.: Sov. radio, p. 608, 1977. (in Russian)

[19] V. S. Pugachev, Theory of random functions and its application to problems of automatic control. M.: Gostekhizdat, p. 659, 1962.(in Russian)

[20] A. A. Sveshnikov, Applied methods of the theory of random functions, Moscow: Nauka, p. 463, 1968. (in Russian)

\section{ПРИНЦИП СТВОРЕННЯ “РОЗУМНОГО ЛІЧИЛЬНИКА ЕЛЕКТРОЕНЕРГІї” В ЕЛЕКТРОГЯГОВИХ МЕРЕЖАХ ЗІ СТОХАСТИЧНИМИ ЕЛЕКТРОМАГНІТНИМИ ПРОЦЕСАМИ}

\author{
Микола Костін, Тетяна Міщенко, \\ Оксана Гоголюк
}

Напруга і струм у тягових мережах систем електричного транспорту постійного струму $є$ різкозмінними випадковими (стохастичними) процесами. Внаслідок цього електронні та гібридні лічильники, які застосовують у таких системах, вимірюють електроенергію з великою відносною похибкою, що істотно перевищує їх клас точності. У цій роботі на основі кореляційної теорії випадкових процесів запропоновано принцип розроблення смарт-лічильників обліку електроенергії, яка передається по тяговій мережі від тягових підстанцій до електрорухомого складу. В основу принципу покладено роботу лічильника в режимі реального часу під час здійснення ним моніторингу не безлічі реалізацій випадкових процесів напруги і струму, а їх детермінованих характеристик - тимчасових функцій математичних очікувань і дисперсій. Експериментальне забезпечення запропонованого принципу продемонстровано на прикладі реєстрації та оброблення реалізацій випадкових процесів напруги і струму, отриманих в умовах реальної експлуатації на ділянці (в фідерній зоні) А-В Придніпровської залізниці України. Отримані для активної та реактивної енергій розрахункові співвідношення, як основа принципу розроблення "розумного лічильника", застосовні не тільки для тягових електромереж, а й для електричних мереж зовнішнього електропостачання систем електричної тяги постійного струму.

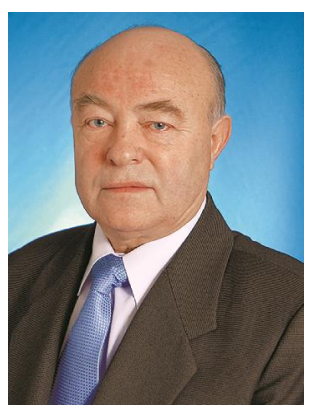

Mykola Kostin graduated from the Dnipropetrovsk Institute of Transport Engineers in electrical engineering in 1961. In 1967 he obtained a $\mathrm{PhD}$ and in 1984 - a DSc.

From 1972 to 2012 he held a position of the head of the department "Theoretical foundations of electrical engineering" at Dnipro National

University of Railway Transport. Now he is a professor of the department "Electrotechnics and Electromechanics" designated by University Published 3 scientific monographs; more than 700 other publications and 30 patents.

Scientific interests - electrodynamics of electrical transport systems. 


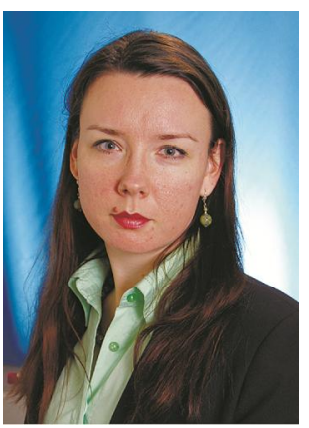

Tetyana Mischenko graduated from Dnipropetrovsk State Technical University in electric drive and automation of industrial installations and technological complexes.

In 2007 obtained $\mathrm{PhD}$ in technical sciences (specialty 05.22.09 - Electric transport).

Published more than 70 publications and 11 methodical works.

From 2008 until now works at the Department of Intelligent Systems and Power Supply at Dnipro National University of Railway Transport named after Academician V. Lazaryan.

Scientific interests: mathematical model of electromagnetic and power-generating processes in electric transport systems.

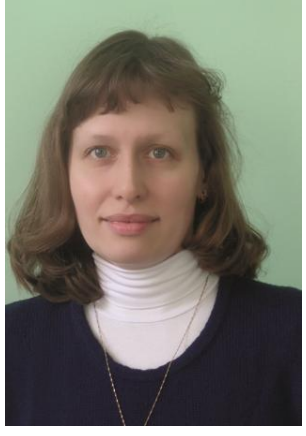

Oksana Hoholyuk - D.Sc, Ass. Professor, graduated from Department of Radiohysics and electronics of Ivan Franko State University of Lviv, Ukraine. She received her Ph.D. and D.Sc degrees in the field of theoretical electrical engineering. Since 2004 she has been working at the Department of Theoretical Electrical Engineering at Lviv Polytechnic National University, Ukraine. Since 2019 she holds a position of a Head of Department of Theoretical and General Electrical Engineering. Her scientific interests are focused on mathematical modelling of electric circuits and systems.

Received: 04.01.2021. Accepted: 10.04.2021 